\title{
Measuring the Economic Efficiencies of OECD Countries in 2019 By Weight- Restricted Data Envelopment Analysis
}

\author{
OECD Ülkelerinin 2019 Yılı Ekonomik Etkinliklerinin Ağırlık Kısıtlı Veri Zarflama Analizi ile \\ Ölçülmesi
}

\author{
Muhammed MARUF \\ Dr. Ö̆gr. Üyesi, Kırşehir Ahi Evran Üniversitesi, İ̈BF, \\ m.maruf@ahievran.edu.tr \\ https://orcid.org/0000-0002-5388-639X
}

Makale Başvuru Tarihi / Received: 17.05.2021

Makale Kabul Tarihi / Accepted: 20.06.2021

Makale Türü / Article Type: Araştırma Makalesi
Anahtar Kelimeler:

$O E C D$,

Veri Zarflama Analizi (VZA),

A ğırlık Kısitll Veri Zarflama Analizi (Güven Bölgesi Modeli).

Keywords:

Economic Efficiency,

Data Envelopment

Analysis (DEA),

Weight Restriicted Data Envelopment Analyisis (ARI DEA)
ÖZET

Benzer nitelikteki girdi ve çıktılar üreterek çok sayldaki organizasyonel karar verme biriminin göreli etkinliklerini ölçen veri zarflama analizi (DEA) doğrusal programlama tabanl bir metottur. Klasik veri zarflama analizi modellerinin dışında belirlenen girdi ve çıtı değişkenlerine ă̆ırlık kısıtları konularak uygulanan Güven Bölgesi (AR) metodu ile karar vericilerin değer yarglları ve tercihleri modele dahil edilebilmektedir. Cünkü klasik veri zarflama analizi modellerinde girdi ve çıktı ağırlıklarının tamamen esnek olması karar verme birimlerine ait göreli etkinlik skorlarında tutarsızlıklara neden olabilmektedir. Böylece normal şartlarda etkin olmayan bir karar verme birimi etkin olarak görünebilmektedir. Bu çalışmada 35 OECD ülkesinin 2019 yll ekonomik etkinliklerini analiz etmek ve etkinlik skorlarına göre bu ülkeleri siralamak amaçlanmıștır. Ülkelerin ekonomik etkinliklerinin ölçülmesinde hem girdi odaklı CCR model hem de ağırlık kısıtll model (ARI DEA) kullanılmıştır. VZA'da ăgırlık kısıtlarının belirlenmesinde kullanılan ikili karșılaștırma değerleri AHP skalasına göre belirlenmiștir. CCR model ile yapılan analizlerde 2019 yllında yedi ülkenin ekonomisi etkin bulunurken, ağırlık kısitll modelde iki ülkenin ekonomisi etkin bulunmuştur. Güven bölgesi modeli ile ă̆ırlık kisitlı olarak yapılan etkinlik analizinde ülkelerin etkinlik değerleri, girdi odaklı CCR modele göre oldukça düşüktür. Bu doğrultuda ăgırlık kisitll modelde kisıtların modele dahil edilmesinin etkinlik değerlerini önemli miktarda değiștirdiği ve ağırlık kısıtlı modelin CCR modele göre etkin olan ve olmayan ülkeleri belirlemede daha güçlü olduğu sonucuna ulaşılmıştır. 


\section{INTRODUCTION}

Efficiency is defined as the relationship among inputs and outputs of organizational decision-making units. Efficiency measurement is carried out for various purposes such as increasing efficiency, control, determining new methods and strategies, and implementing the determined strategies (Demir and Bakırc1, 2014: 111). There are several methods used for efficiency measurement in the literature. One of the methods used to analyze the relative efficiency of organizational decision units is the data envelopment analysis (DEA) method. Developed by Charnes, Choper, and Rhodes (1978), DEA is defined as a linear programming-based method that measures the relative efficiency of a large number of organizational decision-making units by generating multiple inputs and outputs (Tütek et al., 2012: 223).

DEA is a widely used method in the literature. However, in classical DEA models like Charnes, Cooper, and Rhodes (CCR) and Banker, Charnes, and Cooper (BCC), the weights of inputs and outputs are flexible, and the decision-makers do not affect on the model (Vazhayil and Balasubramanian, 2013: 460; Oikonomou et al., 2016: 315; Çakın and Özdemir, 2020: 291). The fact that the input and output weights are completely flexible may cause the relative efficiency scores of the decision-making units determined by the model to be unrealistic (Vazhayil and Balasubramanian, 2013: 460; Oikonomou et al., 2016: 315; Thanassoulis and Allen, 1998: 586). In this context, it has been found that in some models, the important input and output weights of some decision-making units are low, whereas the non-important input and output weights of some are high. This situation causes a decision-making unit that is not usually inefficient to appear efficient. Thus, inconsistencies were found in the relative efficiency scores obtained as a result of the DEA. For this reason, weight restrictions are used to prevent and solve these problems in DEA (Kocakoç, 2003: 4; Çakın and Özdemir, 2020: 291; Oikonomou et al., 2016: 315).

Seeing the results of the economic policies of the countries within a certain economic cooperation organization can be beneficial for both countries and investors. So ,the main objective of this study is to analyze the economic efficiencies of 35 OECD countries in 2019 and to rank these countries according to their efficiency scores. Economic efficiency ranking was made using the input-oriented CCR model and the ARI DEA model. In addition, the other objective of the study is a comparison of the CCR model and ARI DEA model results. In measuring the economic efficiency of OECD countries, unemployment rates, inflation rates, and dollar exchange rates of the countries were used as input variables, and the current account balance, consumer confidence index, and growth data of the countries as output variables. Input and output variables used in the study are the variables accepted as the basic economic indicators in various studies in the literature (Grossman et al., 2013: 19; Ela et al., 2018: 133; Eyüboğlu, 2017: 333). In the DEA, the binary comparison values used in determining the weight restrictions were specified according to the AHP scale, and for this purpose, three economics faculty members shared their opinions, and the binary comparison values determined with a consensus were used.

\section{DATA ENVELOPMENT ANALYSIS (DEA)}

Data envelopment analysis (DEA), which has been used frequently in management sciences and operations research in recent years (Kocakoç, 2003: 1), is a linear programming-based method that measures the relative efficiency of a large number of organizational decision-making units by generating more than one similar input and output (Tütek et al., 2012: 223). DEA was first developed by Charnes, Cooper, and Rhodes (1978), based on the work of Farnell (1957) (Chaparro et al., 1997: 216; Sarraf and Nejad, 2020: 3).

Data envelopment analysis, which requires comprehensive data on inputs and outputs of decisionmaking units with homogeneous and similar characteristics (Chaparro et al., 1997: 216; Stolzer et al., 2018: 58), determines a single relative efficiency score that will enable comparison of decision-making 
units (Eroğlu and Atasoy, 2006: 76). Accordingly, the efficiency score is calculated with the logic given in the following notation (Kocakoç, 2003: 2; Chaparro et al., 1997: 216-217; Sarraf and Nejad, 2020: 3).

Total Weighted Output

\section{Efficiency $=$}

Total Weighted Input

The efficiency scores of the decision-making units range from "0" to "1". The efficiency decreases as the efficiency score approaches 0 , and the efficiency increases as it approaches 1 . Decision-making units with an efficiency score of "1" as a result of DEA are considered efficient (Kelly et al., 2012: 65; Chaparro et al., 1997: 217). The reasons for the failure to achieve efficiency of the decision-making units concluded to be inefficient through DEA can be identified. Then, input and output values that need to be improved to ensure the efficiency of decision-making units can be determined, and so, necessary suggestions about scale size can be made (Behdioğlu et al., 2009: 303; Tütek et al., 2012: 225).

DEA used in measuring the efficiency of homogeneous decision-making units consists of the stages of selecting decision-making units, identifying inputs and outputs, determining the model to be applied in DEA, calculating the relative efficiency of decision-making units, and evaluating and interpreting the efficiency results (Tütek et al., 2012: 228- 230). Two important factors in selecting the decisionmaking units are the homogeneity of these units and the number of decision-making units whose efficiency will be calculated (Behdioğlu and Özcan, 2009: 304; Ramanathan, 2003: 173). There are diverse views in the literature regarding the number of decision-making units. Norman and Stoker (1991) state that the number of decision-making units must be at least twenty. Dyson et al. (2001) state that it must be at least " $2 \mathrm{~m}+\mathrm{n}$ " such that " $\mathrm{m}$ " is the number of inputs and " $\mathrm{n}$ " is the number of outputs (Tütek et al., 2012: 229). On the other hand, Ramanathan (2003: 174) states that the number of decision-making units must be 2 or 3 times the total number of inputs and outputs. While determining inputs and outputs, it is necessary to determine the inputs and outputs that will enable the efficiency of decision-making units to be measured in the best way (Özden, 2008: 176). Inputs and outputs that do not contribute to the efficiency of the decision-making unit and have multiple relationships with each other should not be included in the analysis (Günay, 2015: 21).

The most suitable DEA model for the efficiency calculations of decision-making units must be chosen. The choice of the model may differ according to the input and output, the type of return, or the scale (Ramanathan, 2003: 175). There are many DEA models in the literature. The most widely used models are the CCR model developed by Charness, Cooper, and Rhodes (1978) and the BCC model developed by Banker, Charnes, and Cooper (1984). Charness, Cooper, and Rhodes (CCR) first used DEA to measure the relative efficiency of non-profit organizations. However, in later studies, DEA was widely used to measure the efficiency of all for-profit and non-profit organizations (Özdemir and Demireli, 2013: 216). After the CCR model, Banker, Charnes, and Cooper (1984) put forward the BCC model (Brandao et al., 2020: 1). After the model is determined, separate models are created for all decisionmaking units. DEA models are solved by making the created models into a linear programming model, and the relative efficiency scores of decision-making units are calculated (Tütek et al., 2012: 231). The input-oriented linear DEA model applied in this study is created as follows.

Objective Function:

$$
\begin{aligned}
& \text { Maks } \eta_{k} \\
& =\sum_{r=1}^{s} \mu_{r} y_{r k}
\end{aligned}
$$


Constraints:

$\sum_{i=1}^{m} w_{i} x_{i k}=1$

$\sum_{r=1}^{s} \mu_{r} y_{r j}-\sum_{i=1}^{m} w_{i} x_{i j} \leq 0 \quad(j=1 \ldots . n)$

$\mu_{r}, w_{i} \geq \varepsilon>0 \quad(r=1 \ldots . s)$ and $(i=1 \ldots . m)$

In the above formula;

$\mu_{r}$ : refers to the weight value of rth output,

$y_{r k}:$ refers to the kth output value of the decision-making unit,

$w_{i}$ : refers to the weight value of the ith input,

$x_{i k}$ : refers to the kth input value of the ith decision-making unit.

\section{WEIGHT-RESTRICTED DATA ENVELOPMENT ANALYSIS}

In classical data envelopment analysis models, the optimum results of input and output weights are determined. The reason for this is that it is desired to determine the efficiency of decision-making units to be maximum. (Vazhayil and Balasubramanian, 2013: 460; Oikonomou et al., 2016: 315; Çakın and Özdemir, 2020: 291). However, the fact that the input and output weights are completely flexible can prevent the efficiency scores of the model from being realistic (Vazhayil \& Balasubramanian, 2013: 460; Oikonomou et al., 2016: 315; Thanassoulis \& Allen, 1998: 586).

Some data envelopment analyses indicated that the significant input and output weights of some decision-making units are low. On the other hand, the insignificant input and output weights of some decision-making units were higher. This situation causes the insignificant input and output weights of some decision-making units to be higher than the important ones, and a normally inefficient decisionmaking unit appears to be efficient. Thus, inconsistent results are obtained from the DEA. In this direction, weight restrictions are applied in DEA to solve and prevent these problems (Kocakoç, 2003: 4; Çakın and Özdemir, 2020: 291; Oikonomou et al., 2016: 315).

The input and output variables used in the models may have different levels of importance for decision-makers. In these cases, input and output weights can be calculated using different methods and used in the DEA model, while the value judgments are used in the weight restrictions in DEA. The value judgments are used in the weight restrictions in DEA and reflect the preferences of the decisionmaker in determining the efficiency of the decision-making unit (Kocakoç, 2003: 4). The methods of restricting virtual input and output values, correcting input and output values, and imposing direct constraints on weights are used in order to include value judgments of decision-makers in the model (Özdemir and Demireli, 2013: 223).

In data envelopment analysis, many methods such as absolute weight restrictions, cone-ratio method, and assurance region (AR) are used in the restriction of weights (Kocakoç, 2003: 4). Assurance regions (AR) method is the most frequently used method in the literature. The type of AR method in which the restricted inputs and outputs are associated within themselves is called the ARI method. When input and output weights are associated with each other, it is called ARII (Özdemir and Demireli, 2013: 223). In this context, the assurance region model (AR) is given in the following equation (Keskin and Köksal, 2019: 527; Özdemir and Demireli, 2013: 224); 


$$
\begin{aligned}
a_{i} & \leq \frac{v_{i}}{v_{j}} \leq \beta_{i}(i=1, \ldots, m)(3) \\
\delta_{i} & \leq \frac{u_{r}}{u_{p}} \leq \gamma_{i}(r=1, \ldots, m)
\end{aligned}
$$

$a_{i}$ When the $\beta_{i}, \delta_{i}$ and $\gamma_{i}$ values are generated with the lower and upper limits of the input and output weights, the ARI restrictions are written as follows;

$\frac{L B_{i}}{U B_{j}} \leq \frac{v_{i}}{v_{j}} \leq \frac{U B_{i}}{L B_{i}}$

$\frac{L B_{r}}{U B_{p}} \leq \frac{u_{r}}{u_{p}} \leq \frac{U B_{r}}{L B_{r}}$

The $L B_{i}$ and $U B_{i}$ values in the restrictions represent the lower and upper limits of the $i$ th input variable weight, while the $L B_{r}$ and $U B_{r}$ values represent the lower and upper limits of the $r$. th output variable weight. $i$ and $j$ are elements of inputs and $r$ and $p$ are elements of outputs (Özdemir and Demireli, 2013: 224; Çakın and Özdemir, 2020: 291). The optimal result of the assurance region model is acquired by adding the restrictions to the CCR model. The name Assurance Region (AR) comes from the restriction of the model in a certain region with these restrictions (Özdemir and Demireli, 2013: 224).

\section{LITERATURE REVIEW}

There are lots of studies in the literature on weight-restricted data envelopment analysis. Beasley (1990) used weight-restricted DEA in evaluating chemistry departments of 52 universities. Thompson et al. (1996) used weight-restricted DEA for selecting the location of a nuclear physics laboratory to be established. Thompson et al. (1997) measured the efficiency of 100 banks that operate in the USA using a weight-restricted DEA (Assurance region model). Tarım and Karan (2001) measured the performance of mutual funds in Turkey's capital market with weight-restricted DEA. Kocakoç (2003) demonstrated how to determine weight restrictions in DEA using the analytical hierarchy process (AHP).

Özdemir and Demireli (2013) measured the 2011 and 2012 activities of 21 deposit banks that operate in Turkey using weight-restricted DEA. In the conclusion of the study, the results of the unrestricted DEA model and the results of the weight-restricted model were compared. Hwang et al. (2013) measured the quality of life in 20 cities in Taiwan with a weight-restricted DEA (Assurance region model). Gonzalez et al. (2016) measured the quality of life (health, material living conditions, education, economic and physical security, environment, social interaction, management mentality, and personal activities) of 393 largest municipalities in Spain with weight-restricted DEA. Keskin and Köksal (2018) measured the efficiency of 48 airports, 7 of which are private, using analytical hierarchy process and weight-restricted DEA (assurance region model). GhalehJough et al. (2020) measured the efficiency of 66 branches of a bank that operate in Iran with a weight-restricted DEA. (Çakın \& Özdemir, 2020) measured the innovation performance of 104 countries by using artificial neural networks, analytic network process based on fuzzy Dematel method, and weight-restricted DEA methods in an integrated manner.

As seen in the literature, weight-restricted data envelopment analysis is conducted for efficiency measurement in many different areas. In this study, the economic efficiencies of 35 OECD member countries in 2019 are measured using the weight-restricted DEA. When the literature is examined in this context, we have not come across any study in which weight-restricted DEA was conducted to measure the efficiency of OECD countries. However, there are many studies from different fields using classical DEA to measure the efficiency of OECD countries. Chien and $\mathrm{Hu}$ (2007) measured the macroeconomic and renewable energy efficiency of 45 countries, both OECD and non-OECD 
members, between 2001 and 2002 using DEA. This study used 3 inputs including labor, capital and energy consumption, and 1 output including the gross domestic product. Hsu et al. (2008) measured the efficiency of developed and less developed OECD countries using DEA. The study used 3 inputs including the efficiency of the state, the efficiency of enterprises, and the development level of the infrastructure, and 1 output including the economic performance. Demir and Bakırc1 (2014) measured the 2006-2010 economic efficiencies of 34 OECD member countries using classical DEA. The study used 6 inputs including the unemployment rate, average annual working hours, foreign direct investments, food production index, total imports and tax income, and 6 outputs including the gross national product per capita, comparative price index, purchasing power parity, the total exports, income index and CO2 emissions per capita.Samut and Cafri (2016) measured the hospital efficiency of 29 OECD member countries between 2000 and 2010 using DEA and panel tobit analysis. Aksarayli and Pala (2017) analyzed the life satisfaction of population, economic performance, and innovation levels of 34 OECD member countries using cluster analysis and classical DEA. 4 inputs including the annual average working hours, tax income, import, labor force participation, and 2 outputs including the gross domestic product per capita, and exports were used in the study. Bayrak and Bahar (2018) measured the tourism activity of 34 OECD member countries between 2011 and 2015 using DEA. In the study, 3 inputs including the number of incoming passengers, tourism expenditures, logistics performance index, and 1 output, tourism income, were used.

\section{FINDINGS}

In this study, 35 OECD member countries were ranked according to their economic performance in 2019. Input-oriented CCR model and ARI DEA model were used for ranking the countries according to their economic efficiency. For the efficiency analysis, unemployment rates, inflation rates, and dollar exchange rates of the countries were used as input variables, and current account balance, consumer confidence index, and growth data of countries were used as output variables. Input and output variables used in the study are the variables accepted as the basic economic indicators in various studies in the literature (Grossman et al., 2013: 19; Ela et al., 2018: 133; Eyüboğlu, 2017: 333). For the relative efficiency analysis, three input and three output variables were used, and the number of input and output variables is sufficient for efficiency analysis. Since efficiency analysis in the study will be conducted with the weight-restricted DEA model, the binary comparison values used to define the weights of the input and output variables in the first step were specified according to the AHP scale. For this purpose, the study asked three economics faculty members' opinions and the binary comparison values they determined with a consensus are given in Table 1.

Table 1: Pairwise Comparison Values of Input and Output Variables

PAIRWISE COMPARISON VALUES OF INPUT VARIABLES

\begin{tabular}{lccc}
\hline & Exchange rate (\$) & Inflation $(\%)$ & Unemployment \\
Exchange rate $(\$)$ & - & $1 / 3$ & $1 / 5$ \\
Inflation (\%) & 3 & - & $1 / 3$ \\
Unemployment & 5 & 3 & - \\
\hline
\end{tabular}

$\mathrm{CR}=0,0333$ 
PAIRWISE COMPARISON VALUES OF OUTPUT VARIABLES

$\begin{array}{ccc}\text { Current Account } & \text { Growth Rate } & \text { Consumer Confidence } \\ \text { Balance }(\%) & (\%) & \text { Index }(\%)\end{array}$

\begin{tabular}{cccc}
$\begin{array}{c}\text { Current Account } \\
\text { Balance }(\%)\end{array}$ & $1 / 3$ & 5 \\
Growth Rate $(\%)$ & 3 & - & 7 \\
$\begin{array}{c}\text { Consumer Confidence } \\
\text { Index }(\%)\end{array}$ & $1 / 5$ & $1 / 7$ & - \\
\hline
\end{tabular}

$\mathrm{CR}=0,073$

Unemployment rate, dollar exchange rate, and consumer confidence index variable values are calculated by taking the increase or decrease from the values of the previous year into account. Therefore, the values of these variables were obtained by subtracting 2018 data from 2019 data. Since inflation, current account balance, and growth variables are calculated on an annual basis independently from the previous year's number, 2019 date were used. After the input and output variable values were determined, the input and output data of current account balance, unemployment rate, dollar exchange rate, and consumer confidence index for some countries were found to be negative. For the DEA to give a reliable result, the input and output variable values should not be negative. For this reason, the values of these input and output variables were converted into positive values with the normalization formula given below (Budak, 2011: 102).

$\frac{x_{r j}-x_{j \min }}{x_{j \max }-x_{r j}}$

The input and output variable values to be used in the relative efficiency analysis after normalization were obtained as given in Table 2.

Table 2: Values of Input and Output Variables

OUTPUT VARIABLES

INPUT VARIABLES

$\begin{array}{lcccccc} & \begin{array}{c}\text { Current } \\ \text { Account } \\ \text { Calance }(\boldsymbol{\%})\end{array} & \begin{array}{c}\text { Growth } \\ \text { Rate } \\ (\boldsymbol{\%})\end{array} & \begin{array}{c}\text { Consumer } \\ \text { Confidence Index } \\ (\boldsymbol{\%})\end{array} & \begin{array}{c}\text { Exchange } \\ \text { Rate }\end{array} & \begin{array}{c}\text { Unemployment } \\ (\boldsymbol{\%})\end{array} & \begin{array}{c}\text { Inflation } \\ (\boldsymbol{\%})\end{array} \\ \text { Australia } & 1,295 & 1,940 & 0,37 & 0,005 & 0,640 & 1,611 \\ \text { Austria } & 1,999 & 1,419 & 0,45 & 0,004 & 0,528 & 1,531 \\ \text { Belgium } & 1,217 & 1,744 & 0,46 & 0,004 & 0,417 & 1,437 \\ \text { Canada } & 0,774 & 1,861 & 0,68 & 0,004 & 0,621 & 1,949 \\ \text { Chile } & 0,541 & 1,054 & 0,00 & 0,239 & 0,633 & 2,558 \\ \text { Colombia } & 0,500 & 3,260 & 0,53 & 32,600 & 1,475 & 3,525 \\ \text { Czech Republic } & 1,081 & 2,314 & 0,40 & 0,008 & 0,580 & 2,848 \\ \text { Denmark } & 18,878 & 2,850 & 0,52 & 0,005 & 0,689 & 0,758\end{array}$




\begin{tabular}{|c|c|c|c|c|c|c|}
\hline Estonia & 1,668 & 4,996 & 0,63 & 0,004 & 0,270 & 2,277 \\
\hline Finland & 1,101 & 1,126 & 0,30 & 0,004 & 0,386 & 1,024 \\
\hline France & 1,007 & 1,509 & 1,08 & 0,004 & 0,424 & 1,108 \\
\hline Germany & 6,449 & 0,555 & 0,41 & 0,004 & 0,580 & 1,446 \\
\hline Greece & 0,863 & 1,857 & 1,49 & 0,004 & 0,000 & 0,253 \\
\hline Hungary & 1,095 & 4,578 & 0,55 & 0,072 & 0,575 & 3,339 \\
\hline Iceland & 5,004 & 1,927 & 4,10 & 0,051 & 1,442 & 3,014 \\
\hline Ireland & 0,000 & 5,565 & 0,32 & 0,004 & 0,336 & 0,939 \\
\hline Israel & 2,160 & 3,405 & 0,45 & 0,004 & 0,607 & 0,842 \\
\hline Italy & 2,060 & 0,343 & 0,35 & 0,004 & 0,393 & 0,611 \\
\hline Japan & 2,361 & 0,270 & 0,35 & 0,000 & 0,669 & 0,477 \\
\hline Korea & 2,381 & 2,039 & 0,68 & 0,255 & 0,694 & 0,383 \\
\hline Luxembourg & 2,998 & 2,054 & 0,40 & 0,004 & 0,785 & 1,743 \\
\hline Mexico & 1,070 & 4,339 & 0,48 & 0,004 & 0,837 & 3,636 \\
\hline Netherlands & 21,290 & 2,298 & 0,46 & 0,004 & 0,484 & 2,634 \\
\hline New Zealand & 0,607 & 0,055 & 0,54 & 0,005 & 0,593 & 1,620 \\
\hline Norway & 1,876 & 1,677 & 0,32 & 0,006 & 0,621 & 2,168 \\
\hline Poland & 1,250 & 2,346 & 0,53 & 0,005 & 0,424 & 2,308 \\
\hline Portugal & 1,124 & 0,852 & 0,50 & 0,004 & 0,457 & 0,338 \\
\hline $\begin{array}{l}\text { Slovak } \\
\text { Republic }\end{array}$ & 0,683 & 4,541 & 0,48 & 0,004 & 0,343 & 2,665 \\
\hline Slovenia & 3,906 & 2,236 & 0,28 & 0,004 & 0,382 & 1,631 \\
\hline Spain & 1,727 & 2,317 & 0,34 & 0,004 & 0,213 & 0,700 \\
\hline Sweden & 2,954 & 3,184 & 0,45 & 0,007 & 1,058 & 1,784 \\
\hline Switzerland & 5,585 & 1,950 & 0,40 & 0,004 & 0,544 & 0,363 \\
\hline Turkey & 1,373 & 1,336 & 0,57 & 0,007 & 4,700 & 15,177 \\
\hline United & & & & & & \\
\hline Kingdom & 0,633 & 1,082 & 0,65 & 0,004 & 0,580 & 1,700 \\
\hline United States & 0,747 & 0,917 & 0,61 & 0,004 & 0,589 & 1,812 \\
\hline
\end{tabular}


After determining the input and output variable values, the economic efficiency analysis of the OECD countries in 2019 was carried out with the ARI DEA model, in which input and output variables are weighted separately among themselves. For the relative efficiency analysis, the restrictions given below, which were used in determining input and output variable weights by using the binary comparison matrix in Table 1 , were added to the input-oriented model given in equation \#2.

$$
\begin{array}{lll}
\frac{v_{2}}{3 v_{1}} \geq 0 \Rightarrow v_{2}-3 v_{1} \geq 0 & v_{3}-5 v_{1} \geq 0 & v_{3}-3 v_{2} \geq 0 \\
u_{1}-5 u_{3} \geq 0 & u_{2}-3 u_{1} \geq 0 & u_{2}-7 u_{3} \geq 0
\end{array}
$$

$v_{1}=$ Weight value of Exchange rate input variable

$v_{2}=$ Weight value of Inflation input variable

$v_{3}=$ Weight value of Unemployment input variable

$u_{1}=$ Weight value of Current account balance output variable

$u_{2}=$ Weight value of Grpwth rate output variable

$u_{3}=$ Weight value of Consumer confidence index output variable

After the efficiency analysis was carried out with the assurance region model, an efficiency analysis was performed with the input-based CCR model in order to compare the results obtained. The linear input-oriented CCR model given in equation \#2 was created and the model was solved with the Excel Solver add-in, and the economic efficiency values and economic efficiency ranking of the countries and according to the results obtained are given in Table 3.

The efficiency values given in parentheses in Table 3 are the efficiency values obtained as a result of the super-efficiency analysis. The super efficiency model, which was first applied by Andersen and Petersen (1993), was applied to rank the decision-making units with an efficiency value of "1", that is, effective decision-making units, and the results were given in parentheses (Özdemir and Demireli, 2013: 222).

Table 3: Economic Efficiency Values and Ranking Values of OECD countries

CCR MODEL

\begin{tabular}{lcclcc}
\hline \multicolumn{1}{c}{ Countries } & $\begin{array}{c}\text { Efficiency } \\
\text { Values }\end{array}$ & $\begin{array}{c}\text { Ranking } \\
\text { Values }\end{array}$ & \multicolumn{1}{c}{ Countries } & $\begin{array}{c}\text { Efficiency } \\
\text { Values }\end{array}$ & $\begin{array}{c}\text { Ranking } \\
\text { Values }\end{array}$ \\
Japan & $1(3,229)$ & 1 & Denmark & $1(1,243)$ & 1 \\
Denmark & $1(2,056)$ & 2 & Greece & $1(1,193)$ & 2 \\
Greece & $1(1,982)$ & 3 & Ireland & 0,807 & 3 \\
Ireland & $1(1,731)$ & 4 & Korea & 0,803 & 4 \\
Netherlands & $1(1,600)$ & 5 & Israel & 0,565 & 5 \\
Estonia & $1(1,102)$ & 6 & Switzerland & 0,393 & 6 \\
Switzerland & $1(1,003)$ & 7 & Spain & 0,311 & 7 \\
Slovak Republic & 0,872 & 8 & Estonia & 0,299 & 8 \\
Korea & 0,803 & 9 & Netherlands & 0,285 & 9
\end{tabular}


Maruf, Muhammed - Measuring the Economic Efficiencies of OECD Countries in 2019 By Weight-Restricted Data Envelopment Analysis

\begin{tabular}{|c|c|c|c|c|c|}
\hline Israel & 0,767 & 10 & Slovak Republic & 0,208 & 10 \\
\hline Mexico & 0,762 & 11 & Sweden & 0,207 & 11 \\
\hline France & 0,663 & 12 & France & 0,191 & 12 \\
\hline Spain & 0,659 & 13 & Hungary & 0,187 & 13 \\
\hline Slovenia & 0,539 & 14 & Japan & 0,187 & 14 \\
\hline Canada & 0,515 & 15 & Luxembourg & 0,185 & 15 \\
\hline Belgium & 0,483 & 16 & Germany & 0,179 & 16 \\
\hline Germany & 0,471 & 17 & Portugal & 0,178 & 17 \\
\hline Luxembourg & 0,468 & 18 & Belgium & 0,171 & 18 \\
\hline Poland & 0,452 & 19 & Australia & 0,169 & 19 \\
\hline Portugal & 0,405 & 20 & Mexico & 0,162 & 20 \\
\hline Austria & 0,404 & 21 & Finland & 0,161 & 21 \\
\hline Sweden & 0,404 & 22 & Slovenia & 0,157 & 22 \\
\hline United Kingdom & 0,403 & 23 & Italy & 0,153 & 23 \\
\hline United States & 0,366 & 24 & Austria & 0,145 & 24 \\
\hline Australia & 0,357 & 25 & Canada & 0,13 & 25 \\
\hline Finland & 0,312 & 26 & Colombia & 0,126 & 26 \\
\hline Italy & 0,299 & 27 & Poland & 0,122 & 27 \\
\hline Norway & 0,275 & 28 & Iceland & 0,121 & 28 \\
\hline Czech Republic & 0,266 & 29 & Czech Republic & 0,11 & 29 \\
\hline Iceland & 0,263 & 30 & Norway & 0,092 & 30 \\
\hline New Zealand & 0,249 & 31 & United Kingdom & 0,073 & 31 \\
\hline Hungary & 0,186 & 32 & United States & 0,059 & 32 \\
\hline Turkey & 0,15 & 33 & Chile & 0,055 & 33 \\
\hline Colombia & 0,126 & 34 & Turkey & 0,012 & 34 \\
\hline Chile & 0,056 & 35 & New Zealand & 0,011 & 35 \\
\hline
\end{tabular}




\section{CONCLUSION}

Measuring the economic efficiency of countries has a significant impact on issues such as the risk level of countries, investor behavior, credit rating, capital markets, and loan costs. The country risk ranking of countries that are better than other countries in terms of economic efficiency decreases, their capital markets improve, and more foreign investors choose to make investments in these countries. Many criteria are used to identify the economic efficiencies of the countries and to rank them accordingly. For this reason, multi-criteria decision-making methods are mostly used in economic efficiency measurements. In this context, classical DEA (CCR model) that measures relative efficiency scores of multiple decision-making units by generating multiple inputs and outputs and weight-restricted DEA (ARI DEA model) in which weight restrictions are applied to determine input and output variables were used to measure the economical efficiencies of the countries in this study.

The purpose of the study is to measure the economic efficiencies of 35 OECD countries in 2019 and to rank these countries according to their efficiency scores. In measuring the economic efficiency of OECD countries, unemployment rates, inflation rates, and dollar exchange rates of the countries were used as input variables and the current account balance, consumer confidence index, and growth data of the countries as output variables. The unemployment rate, dollar exchange rate, consumer confidence index values were calculated by subtracting 2018 data from 2019 data. As for inflation, current account balance, and growth variables, 2019 data were used. Binary comparison values to be used in determining weight restrictions in DEA were determined according to the AHP scale. For this purpose, the views of three economics faculty members were taken and the binary comparison values determined with a consensus were used as weight restrictions.

In the analyses conducted with the classical DEA (CCR model), the economies of seven OECD countries were found to be efficient in 2019. When these countries are ranked according to the calculated super efficiency values, they are listed as Japan, Denmark, Greece, Ireland, Netherland, Estonia, and Switzerland. According to the efficiency values, it was found that Japan was the most economically efficient country in 2019 according to the CCR model. In addition, weight restrictions were added to the variables determined as input and output in the study in line with the studies in the literature and expert views, and a relative efficiency analysis was made with the assurance region model. In the analyses conducted with the weight-restricted model (ARI DEA) created in this direction, the economies of the two OECD countries were found to be effective in 2019. According to the calculated super efficiency values, these countries are Denmark and Greece. In the weightrestricted model (ARI DEA), Denmark is seen to be the most economically efficient country in 2019.

In the efficiency analysis performed with weight-restricted with the assurance region model, the efficiency values of the countries were found to be quite low compared to the efficiency results obtained from the input-oriented CCR model. The economic efficiency ranking of the countries in the weight-restricted model has changed considerably compared to the CCR model. For example, although Japan ranked 1st in the efficiency analysis carried out using the input-based CCR model, it was not found effective due to the low weights of the input and output variables, which had advantageous values in the weight-restricted model. The weight-restricted model provided healthier results by allowing variables that are more important in economic evaluation to be taken into account with greater weight in efficiency calculations. Accordingly, as a result, putting restrictions in the weightrestricted model significantly changes the efficiency values and the weight-restricted model is a superior method for identifying the active and inactive countries compared to the CCR model. In addition, different weight restrictions can be used depending on the input and output selection in the efficiency analysis performed with weight-restricted DEA. Different restrictions, which may vary according to the value judgment of decision makers and market data, may give different results. 


\section{REFERENCES}

AKSARAYLI, M., \& PALA, O. (2017). "Veri Zarflama Analizi ve Kümeleme Analizi Kullanılarak OECD'ye Üye Ülkelerin Ekonomik Performansları, Yaşam Memnuniyeti ve İnovasyon Düzeyleri Açısından İncelenmesi”, Aydın İktisat Fakültesi Dergisi, S. 2(2), pp. 67-80.

BAYRAK, R., \& BAHAR, O. (2017). "Economic efficiency analysis of tourism sector in OECD countries: An emprical study with DEA”. Uluslararası İktisadi ve İdari İncelemeler Dergisi, S.20, pp. 83-100.

BANKER, R. D., CHARNES, A., \& COOPER, W. W. (1984). "Some Models For Estimating Technical And Scale Inefficiencies In Data Envelopment Analysis", Management Science, S.30, 1078-1092.

BEASLEY, J.E. (1990). “Comparing University Departments”, OMEGA, S. 18(2), pp. 171-183.

BEHDİOĞLU, S., \& ÖZCAN G. (2009). "Veri Zarflama Analizi Ve Bankacıllı Sektöründe Bir Uygulama", Süleyman Demirel Üniversitesi İktisadi ve İdari Bilimler Fakültesi Dergisi, S. 14 (3), pp. 301-326.

BRANDAO, L. C., SOARES DE MELlO, J. C. C. B., \& DEL-VECCHIO, R. R. (2020). "A Linear Model for Smooth DEA BCC Frontiers", Computers and Industrial Engineering, S. 140(May 2019),

BUDAK, H. (2011). "Veri Zarflama Analizi ve Türk Bankacılık Sektöründe Uygulaması”, Marmara Üniversitesi Fen Bilimleri Dergisi, S. 23(3), pp. 95-110.

CHARNES, A., W. COOPER, \& E. RHODES. (1978). "Measuring The Efficiency of Decision Making Units”, European Journal of Operational Research, S. 2(6), pp. 429-444.

CHAPARRO, P., F., JIMENEZ, S., J., \& SMITH, P. (1997). “On The Role Of Weight Restrictions In Data Envelopment Analysis”, Journal of Productivity Analysis, S. 8(2), pp. 215-230.

CHIEN, T., \& HU, J. L. (2007). "Renewable Energy and Macroeconomic Efficiency Of OECD And Non-OECD Economies", Energy Policy, S. 35(7), pp. 3606-3615.

ÇAKIN, E., \& ÖZDEMIR, A. (2020). “Ülkelerin Inovasyon Performansının Ölçülmesinde Yapar Sinir Ağları, Bulanık Demantel Tabanlı Analitik Ağ Süreci ve Ağırlık Kısıtlı Veri Zarflama Analizi Yaklaşımlarının Bütünleşik Olarak Kullanılması Ve Bir Uygulama”. Dokuz Eylül Üniversitesi İşletme Fakültesi Dergisi, $S .2$ (21), pp. 287-314.

DEMİR, A., \& BAKIRCI, F. (2014). "OECD Üyesi Ülkelerin Ekonomik Etkinliklerinin Veri Zarflama Analizi ile Ölçümü’, Atatürk Üniversitesi İktisadi ve İdari Bilimler Dergisi, S. 28 (2), pp.109-132.

ELA, M., DOĞAN, A., \& UÇAR, O. (2018). “Avrupa Birliği Ülkeleri Ve Türkiye'nin Makroekonomik Performanslarının Topsis Yöntemi İle Karşılaştırılması", Osmaniye Korkut Ata Üniversitesi İktisadi ve İdari Bilimler Fakültesi Dergisi, S. 2(2), pp. 129-143.

EROĞLU, E., \& ATASOY, M. C. (2006). "Veri Zarflama Analizi İle Etkinlik Ölçümü ve Etkin Karar Birimlerinin Duyarlılık Analizi”, İ.Ü. İşletme Fakültesi Dergisi. S. 35 (2), pp. 73-89.

EYÜBOĞLU, K. (2017). “Türk Dünyasinda Yer Alan Ülkelerin Makro Performanslarinin Karşilaştirilmasi”, Bilig, S. 83, pp. 331-350.

FARRELL, M. J. (1957). "The Measurement of Productive Efficiency", Journal ofthe Royal Statistical Society Series A, S. (120), pp. 253-290.

GHALEHJOUGH, R., S., HOSSEINZADEH L., F., JAHANSHAHLOO, G., ROSTAMYMALKHALIFEH, M., \& SHARAFI, H. (2020). "Finding Closest Target for Bank Branches in The Presence of Weight Restrictions Using Data Envelopment Analysis", Annals of Operations Research, C. 288 
GROSSMAN, V., N., MACK, A., \& MARTINEZ-GARCIA, E. (2013). "Database of global economic indicators (DGEI): A methodological Note", Inside Federal Reserve Bank of Dallas, Globalization and Monetary Policy Institute Working Papers (C. 2013).

GONZALEZ, E., CÁRCABA, A., \& VENTURA, J. (2016). "Weight constrained DEA measurement of the quality of life in Spanish municipalities in 2011", Social Indicators Research, S.136(3), pp. $1157-1182$

GÜNAY, B. (2015). "BİST'de İşlem Gören KOBİ Gıda İşletmelerinin Veri Zarflama Analizi Yöntemi İle Etkinliklerinin Ölçülmesi”, Akademik Bakış Dergisi, S. 47, pp. 16-34.

HSU, M., LUO, X., \& CHAO, G. H. (2008). "The Fog Of OECD and Non-OECD Country Efficiency: A Data Envelopment Analysis Approach”, The Journal of Developing Areas, pp. 81-93.

HWANG, S. N., LEE, H. S., TANG, S. C., \& Hsu, S. S. (2013). "Measuring Quality of Life Using DEA-AR: Focusing on Undesirable Factors", Information Systems and Operational Research, S. 51(2), pp. 84-91.

KELLY, E., SHALLOO, L., GEARY, U., KINSELLA, A., \& WALLACE, M. (2012). “Application of data envelopment analysis to measure technical efficiency on a sample of Irish dairy farms", Irish Journal of Agricultural and Food Research, S.51, pp. 63-77.

KESKIN, B., \& KÖKSAL, C. D. (2019). "A Hybrid AHP/DEA-AR Model for Measuring And Comparing The Efficiency of Airports". International Journal of Productivity and Performance Management, S. 68(3), pp. 524-541.

KOCAKOÇ, İ. D. (2003). "Veri Zarflama Analizi’ndeki Ağırlık Kısıtlamalarının Belirlenmesinde Analitik Hiyerarşi Sürecinin Kullanımı”, Dokuz Eylül Üniversitesi İktisadi İdari Bilimler Fakültesi Dergisi, S. 18(2), pp. 1-12.

OIKONOMOU, N., TOUNTAS, Y., MARIOLIS, A., SOULIOTIS, K., ATHANASAKIS, K., \& KYRIOPOULOS, J. (2016). "Measuring The Efficiency of The Greek Rural Primary Health Care Using a Restricted DEA Model; The Case of Southern And Western Greece", Health Care Management Science, S. 19(4), pp. 313-325.

ÖZDEMIR, A., \& DEMIERLI, E. (2013). “Ağırlık Kısıtlı Veri Zarflama Analizi ile Mevduat Bankalarının Etkinlik Ölçümüne Yönelik Bir Uygulama”, Uluslararası Yönetim İktisat ve İşletme Dergisi, S. 9(19), pp. 215-238.

ÖZDEN, H. Ü. (2008). "Veri Zarflama Analizi ile Türkiye'deki Vakıf Üniversitelerinin Etkinliğinin Ölçülmesi”. İstanbul Üniversitesi İşletme Fakülttesi Dergisi. S. 37 (2), pp. 167-185.

RAMANATHAN, R. (2003). An Introduction to Data Envelopment Analysis a Tool for Performance Measurement. New Delhi: Sage Publications.

SAMUT, K., P., \& CAFRI, R. (2016). "Analysis of The Efficiency Determinants of Health Systems in OECD Countries by DEA And Panel Tobit”. Social Indicators Research, S. 129(1), pp. 113-132.

SARRAF, F., \& NEJAD, S. H. (2020). "Improving Performance Evaluation Based On Balanced Scorecard With Grey Relational Analysis And Data Envelopment Analysis Approaches: Case Study In Water And Wastewater Companies", Evaluation and Program Planning, S. 79(November 2019)

STOLZER, A. J., FRIEND, M. A., TRUONG, D., TUCCIO, W. A., \& AGUIAR, M. (2018). "Measuring and Evaluating Safety Management System Effectiveness Using Data Envelopment Analysis" Safety Science, S. 104(January), pp. 55-69.

TARIM, S. A., \& KARAN, M. B. (2001). "Investment Fund Performance Measurement Using Weight-Restricted Data Envelopment Analysis: An Application to The Turkish Capital Market", Russian and East European Finance and Trade, S. 37(5), pp.64-84. 
THANASSOULIS, E., \& ALLEN, R., (1998), "Simulating Weights Restrictions in Data Envelopment Analysis by Means Of Unobserved Dmus”, Management Science, S. 44(2), pp. 586-594.

THOMPSON, R.G., SINGLETON, F.D., THRALL, R.M., \& SMITH, B.A., (1986), “Comparative Site Evaluations for Locating a High-Energy Physics Lab in Texas", Interfaces, S. 16:6, pp. 35-49.

THOMPSON, R. G., BRINKMANN, E. J., DHARMAPALA, P. S., GONZALEZ-LIMA, M. D., \& THRALL, R. M. (1997). DEA/AR Profit Ratios and Sensitivity of 100 Large U.S. Banks. European Journal of Operational Research, S. 98, pp. 213-229.

TÜTEK, H., GÜMÜŞOĞLU Ş. \& ÖZDEMIR, A. (2012). Sayısal Yöntemler Yönetsel Yaklaşım. İstanbul. Beta Basım Yayım.

VAZHAYIL, J. P., \& BALASUBRAMANIAN, R. (2013). “Optimization of India's Power Sector Strategies Using Weight-Restricted Stochastic Data Envelopment Analysis”, Energy Policy, S. 56, pp. 456-465. 